Lu, C-Q., Lu, J.J., Du, D.Y., \& Brough, P. (2016). Crossover effects of work-family conflict among Chinese couples. Journal of Managerial Psychology, 31(1), 235-250.

\title{
Crossover Effects of Work-Family Conflict among Chinese Couples
}

\begin{abstract}
Purpose - The study aims to investigate the crossover effects of one partner's work-family conflict (WFC) on the other partner's family satisfaction, physical well-being and mental well-being. The study tests the moderating effect of the opposite partner's family identity salience within the crossover process in a Chinese context.

Design/methodology/approach - A self-administered questionnaire was used to collect matched data from 212 Chinese dual-earner couples. Hierarchical multiple regression analysis was employed to test the research hypotheses.

Findings - The results showed that there were significantly negative crossover effects of husbands' WFC on their wives' family satisfaction, physical well-being, and mental well-being, and vice versa. We found that the wives' family identity salience mitigated the crossover effects of the husbands' WFC, but the husbands' family identity did not moderate the crossover effect of the wives' WFC.

Originality/values - This is the first study to investigate the crossover effects of work-family conflict (WFC) among dual-earner couples in China. Further, the study integrated family identity salience into the WFC crossover process between couples from the receiver's view and provided evidence that partners differed in the ways they dealt with each other's stress. This research advances scholarly discussions of the psychological crossover process and fills a key gap of considering complex role variables as moderators within this crossover process.
\end{abstract}


Keywords Crossover effect, Dual-earner couples, Work-family conflict, Family identity salience, Family satisfaction, Physical well-being, Mental well-being.

\section{Introduction}

Work and family are the two central domains for most adults. With increasing work demands, pressures from the work domain increasingly intrude on family and personal life and may lead to work-family conflict (WFC). WFC has been shown to negatively impact individuals' well-being, role satisfaction and performance in both work and family domains (e.g., Allen et al., 2000). Moreover, WFC has also been found to affect the people with whom one is intimately connected, especially the spouse. Crossover effects between spouses refer to the process by which a stressor or strain experienced by one partner affects the other partner's level of stress or strain (Westman, 2002), indicating an inter-individual transmission of stressors or strain. Evidence has shown that burnout, role and marital dissatisfaction, distress, and work-family conflict may transfer from one spouse to the other (e.g., Ten Brummelhuis et al., 2010; Westman et al., 2004). However, there have been relatively few studies investigating the crossover effects of WFC on the other spouse's well-being and role satisfaction (e.g., Bakker et al., 2008). This is unfortunate because WFC is one of the central variables in the work-family literature from a stress perspective.

Gender differences in work and family experiences has been frequently studied in work-family research to date (Korabik et al., 2008); however, evidence about the direction of the crossover effect between the genders is mixed. Some studies have found uni-directional crossover from husbands to wives or from wives to husbands (e.g., Ten Brummelhuis et al., 2010), and other research reports bi-directional crossover (e.g., Bakker et al., 2008). These inconsistencies may be attributed to gender differences in work/family role salience, rather than gender per se, that influence the crossover effect (Brough et al., 2009; Powell and 
Greenhaus, 2010). Eby et al. (2005) stated that a pertinent gap in the literature related to WFC crossover is that researchers were not examining complex role variables, such as role salience. Role salience or role identity salience may influence the intensity of the stress experienced within the crossover process. When proposing a model for WFC study, Greenhaus and Beutell (1985) suggested that role salience may have both a direct effect and a moderating effect on the role pressure-WFC relationship. The current study extends these discussions by investigating the moderation of family identity salience on the sender's (husband or wife) WFC crossover effects on the receiver's (wife or husband) levels of psychological strain, including family satisfaction and well-being. Moreover, the majority of crossover studies assume the receiver was the passive recipient of stress or strain from the sender during the crossover process and made little attempt to assess how much the receiver's individual difference variables can buffer or exacerbate the extent of this crossover effect.

In the current study, we focus on the role of the receiver's family identity salience within the crossover process. Family identity salience is defined as the subjective importance a person attaches to his or her family role (Thoits, 1991), which can influence an individual's vulnerability to work-family conflict (Brough et al., 2009; Greenhaus and Beutell, 1985), especially for dual-earner couples. We believe that taking family identity salience into account might contribute further to our understanding of the complex crossover effect of WFC. This research, therefore, directly responds to Westman's call (2002) for more studies to explore which variables could buffer or intensify the crossover process.

To date, the majority of studies investigating the crossover process have been conducted within individualistic Western countries; very little is known about whether these results are applicable to the collectivistic Chinese society, which has a different philosophy towards work and family (Redding, 1993). We believe that China offers an ideal setting to study the 
crossover effect of WFC. China has the highest percentage (more than 90\%) of dual-earner couples in the world (Lu et al., 2000), which may intensify WFC because of multiple-role demands. Additionally, family is highly valued in the Chinese collectivist culture, while extra working time is regarded as self-sacrifice for the benefit of family (Redding, 1993; Triandis, 2004). Thus, these differences lead us to believe that it is vital to study the possible impact of WFC on Chinese families.

Thus, the purpose of the study is twofold. First, we examine whether the WFC of one partner is negatively related to the other partner's family satisfaction and well-being among Chinese dual-earner couples. Second, we aim to investigate whether the other partner's (the receiver's) family identity salience moderates this crossover process, which directly address a recognized gap in the literature pertaining to WFC crossover (Eby et al., 2005; Westman et al., 2009). We anticipate that our findings will shed light on the inconsistencies in previous crossover effect research related to gender differences, thereby helping us to gain a fuller understanding of work-family issues.

\section{The Crossover Effect of Work-Family Conflict among Couples}

The crossover effect occurs when one partner's stress and strain affects the other partner's level of stress or strain, and vice versa. Any feature of the environment that harms, threatens or challenges an individual is referred to as a stressor, while the individual's responses are generally called strains (O'Driscoll et al., 2009). In this study, we focus on WFC, a prevalent role stressor in the current workplace (Allen et al., 2000), and use Chinese dual-earner couples as the research sample. WFC is defined as "a form of inter-role conflict in which the role pressure for the work and family domains are mutually incompatible in some respect" (Greenhaus and Beutell, 1985, p.77), including work interference with family and family interference with work. WFC encompasses three different forms of inter-role conflicts: time-based, strain-based, and behavior-based (Brough and O'Driscoll, 2005; Carlson et al., 
2000). We chose family satisfaction, physical well-being and mental well-being as indicators of strains.

WFC and its crossover effects have been investigated. Hammer et al.(1997) found that one partner's WFC accounted for variance in the other partner's WFC beyond the within-individual factors. Westman and Etzion (2005) reported crossover of WFC from women in the Air Force to their spouses and vice versa. Similar findings were repeated by sampling Israeli Jewish dual-earner parents (Cinamon et al., 2007). The studies all demonstrated a "stressor-stressor" crossover effect because WFC can be conceptualized as a form of role stressor (e.g., Greenhaus and Beutell, 1985). There also exists a "stressor-strain" crossover effect (Westman, 2002). For example, Bakker et al. (2008) found that one partner's WFC had a crossover effect on the other partner's emotional exhaustion. In a diary study, Song et al. (2011) also demonstrated that one partner's WFC crossover negatively impacted the marital satisfaction of the other partner. In the current study, we test this point further by assessing three strain outcomes: family satisfaction, physical well-being and mental well-being.

According to the conservation of resources (COR) theory (Hobfoll, 1989), individuals seek to acquire and maintain resources. Strain is a reaction to an environment in which there is a threat of a loss of resources, an actual resource loss, or lack of an expected resource gain. Because couples consist of two individuals who live together and share family responsibility, one partner would experience the threats of actual or potential resource loss when the other partner experiences WFC. For example, if one partner works overtime and is unable to undertake domestic chores, the other partner has to use his or her own resources (i.e., time or energy) to complete these domestic demands. These resource-depleting behaviors may lead to a negative "state of being", such as dissatisfaction, depression, or physiological tension (Grandey and Cropanzano, 1999; Westman et al., 2009). 
In line with these theoretical arguments, we therefore hypothesize:

Hypothesis 1: Husbands' WFC is negatively correlated with their wives' family satisfaction (Hypothesis 1a), physical well-being (Hypothesis 1b), and mental well-being (Hypothesis 1c).

Hypothesis 2: Wives' WFC is negatively correlated with their husbands' family satisfaction (Hypothesis 2a), physical well-being (Hypothesis 2b), and mental well-being (Hypothesis 2c).

\section{The Moderating Effects of Family Identity Salience}

Role-identity is a key concept in identity theory. It refers to "the internalized sets of role expectations, with the person having as many identities as roles played in distinct sets of social relationships" (Stryker, 1987, p. 90). Although individuals usually identify with multiple roles, not all of these roles are equally important to their personal identity. The concept of role identity salience captures the subjective importance of a role to an individual (Thoits, 1991). For one person, family role identity may be more important and precede the level of work identity. For another person, work role identity may be the dominant aspect of the self, taking priority over other identities. Given freedom of choice, individuals will act and behave in accordance with the internalized expectations associated with roles that are higher in their identity hierarchies (Stryker and Serpe, 1994). This process is known as a self-verification or an identity-verification process (Burke, 1991). In the present study, we are particularly interested in an individuals' family role identity salience because we focus on family satisfaction as an outcome.

Whilst previous research has found that family role identity was positively related to individuals' experiences of WFC (e.g., Greenhaus and Powell, 2003), family identity salience could bring some form of reward to individuals. Accumulated evidence indicates that the more salient a particular life role is to an individual, the more likely he or she is to invest time, 
affection, and energy into the role, thus experiencing more enjoyment and better role performance (e.g., Lu et al., 2011; Warner and Hausdorf, 2009). Furthermore, Bagger and colleagues $(2008 ; 2012)$ recently found that family identity salience could alleviate the negative consequences of family and work interference on individuals' family satisfaction and psychological distress. They argued that those with higher levels of family identity salience were willing to invest more resources in family and to accommodate any resource loss. We extended the above studies to examine the impact of family identity salience on the WFC crossover effects among dual-earner couples.

According to COR theory (Hobfoll, 1989), resources are categorized as conditions, objects, energies, and personal characteristics. These are valued in their own right or act as a means of attaining other conditions, objects, energies and personal characteristics. In reference to the importance or centrality of family role to one's self-concept, family identity salience is considered a personal characteristic. There is supporting evidence that the more salient a family role identity, the more strongly an individual commits to his or her family role (e.g., Carlson and Kacmar, 2000; Powell and Greenhaus, 2010). Family role commitment may help an individual achieve valued resources, such as skills, support, role satisfaction and performance (Hobfoll, 2001). Thus, family role identity salience is treated as a key personal resource that could help individuals maintain and build more resources to buffer against the effects of WFC.

Furthermore, Stryker (1968) suggested that the higher an identity is in the salience hierarchy, the higher the probability that a person will perceive a given situation as an opportunity to perform in terms of that identity. Their partners' WFC may even provide them with an opportunity to self-verify their family identity. Studies have demonstrated that when individuals fulfill their self-verification through good role performance, their self-esteem in that domain rises (e.g., Burke and Stets, 1999). In our case, through family devotion and 
self-verification process, individuals with high family identity salience may feel a sense of fulfillment of their life or gain more personal resources. For this reason, family identity salience is likely to provide a partner with more opportunities to obtain a gain in net resources despite the demands arising from their partner's levels of WFC.

COR theory also suggests that people protect and conserve the resources that are most critical to their self-identity (Hobfoll, 2001). Thus, the greater the given role identity salience, the more valued the resource should be, and the more an individual should behave in a way to minimize loss of that resource, which can buffer the harmful impacts of stressors. In contrast, individuals with low family identity salience have fewer resources available to compensate for the resource loss and to prevent further loss when their partners are suffering from WFC. They thus may experience reductions in family satisfaction and well-being compared with individuals with higher levels of family identity salience. Because the crossover effects of WFC are hypothesized to be bi-directional (see Hypotheses 1 and 2), we also expect that the moderating effect of family identity salience is bi-directional for both wives and husbands, hence we hypothesize:

Hypothesis 3: Wives' family identity salience attenuates the negative relationships between their husbands' WFC and their own family satisfaction (Hypothesis 3a), physical well-being (Hypothesis 3b) and mental well-being (Hypothesis 3c).

Hypothesis 4: Husbands' family identity salience attenuates the negative relationships between their wives' WFC and their own family satisfaction (Hypothesis 4a), physical well-being (Hypothesis 4b) and mental well-being (Hypothesis 4c).

\section{METHOD}




\section{Participants and Procedure}

The participants in our study were dual-earner couples from ten major cities in China. A total of 330 pairs of questionnaires were distributed to the targeted research participants. The participants were given two identical questionnaires and asked to give one to their spouse, and the completed anonymous questionnaires were returned directly to the researchers. We received 247 pairs of questionnaires, resulting in a response rate of $75 \%$. For research purposes, we only included those couples who met the eligibility criterion of dual-earner couples, producing a final sample of 212 couples.

The respondent males were slightly older than the females (males $M=35.65$ years, $S D=$ 4.51; females $M=33.94$ years, $S D=4.46$ ). Approximately $66 \%$ of the couples had at least one dependent child, and $41 \%$ had dependent elders who lived with them. Our sample consisted of professional post-doctoral families, which means at least one of the couples was employed in a post-doctoral position at a university or research institute. Approximately $74 \%$ of the post-doctorate sample was male. Nearly all of the male respondents $(n=210 ; 99 \%)$ and the female respondents $(n=189 ; 89 \%)$ had a bachelor's degree, while approximately $83 \%$ of the males $(n=174)$ and $20 \%$ of the females $(n=38)$ had a doctoral degree.

\section{Measures}

Work-family conflict (WFC). Work-family conflict was assessed using the Chinese version (Spector et al., 2007) of Carlson et al.'s (2000) scale. This measure consists of nine work-family items and nine family-work items across three dimensions of conflict (strain-based, time-based and behavior-based), respectively. A sample item is "The time I spend on family responsibilities often interferes with my work responsibilities". Each item was rated on a five-point scale from 1 (totally disagree) to 5 (totally agree). WFC was treated as a composite measure, an aggregation of all six dimensions of conflict, so we performed second-order confirmatory factor analysis to verify the nature of the construct. 
The results supported a second-order factor model for WFC, with the six dimensions of conflict as first-order factors and one second-order factor in both the male $\left(\chi^{2} / d f(383.78 / 129)\right.$ $=2.98 ; \mathrm{SRMR}=.09 ; \mathrm{CFI}=.90 ; \mathrm{NFI}=.90)$ and female samples $\left(\chi^{2} / d f(413.01 / 129)=3.22\right.$ SRMR $=.08 ; \mathrm{CFI}=.93 ; \mathrm{NFI}=.91$ ), with significant and high factor loadings (larger than .45). The between-group chi-square difference test $\left(\Delta \chi^{2}=15.7, \Delta d f=12, p>.05\right)$ also indicated non-significance.

Family Satisfaction. Family satisfaction was measured using a three-item scale developed by Edwards and Rothbard (1999). An example item is "Generally, I am satisfied with my family life." Each item was rated on a six-point scale from 1 (totally disagree) to 6 (totally agree). Physical Well-being and Mental Well-being. The Chinese version (Siu et al., 2005) of the Well-Being scale of ASSET (Cartwright and Cooper, 2002) was used to measure both physical well-being (ten items, e.g., lack of appetite) and mental well-being (ten items, e.g., impatience). Each item was rated on a six-point frequency scale from 1 (never) to 6 (frequently) in terms of the symptoms' occurrence within the last three months. The scores were reversed, and higher scores indicated higher levels of well-being.

Family identity salience. We measured family identity salience using four items from the career identity salience scale (Lobel and St. Clair, 1992). A sample item is "I am very much personally involved in my family". Each item is rated on a seven-point scale from 1 (totally disagree) to 7 (totally agree).

The survey instruments were written in Chinese. The translation and back translation procedures were performed on measures without existing Chinese versions.

\section{RESULTS}

Table 1 presents the means, standard deviations, and correlations for the variables, and all alpha coefficients were above .70. A MANOVA was conducted to test gender difference in 
research variables. The results $(F(5,379)=3.15, p<.05)$, and the result of subsequent ANOVA indicated that the wives reported higher levels of family identity salience $(F(1,383)$ $=6.08, p<.05)$ than their husbands did, and differences in the others were non-significant.

\section{【Insert Table 1 about here】}

After controlling for age, education level, and dependents, husbands' WFC was negatively related to wives' family satisfaction $(\beta=-.23, p<.01)$, physical well-being $(\beta=$ $-.20, p<.01)$ and mental well-being $(\beta=-.16, p<.05)$ as shown in Table 2. Similarly, wives' WFC was negatively related to the husbands' family satisfaction $(\beta=-.32, p<.001)$, physical well-being $(\beta=-.22, p<.01)$ and mental well-being $(\beta=-.23, p<.01)$ as shown in Table 3 . Therefore, Hypotheses $1 \mathrm{a}-1 \mathrm{c}$ and $2 a-2 \mathrm{c}$ were supported.

\section{【Insert Tables 2 and 3 about here】}

Table 2 also shows that the wives' family identity salience significantly interacted with the husbands' WFC relative to family satisfaction, and physical and mental well-being ( $\beta_{\text {family }}$ satisfaction $\left.=.38, p<.05 ; \beta_{\text {physical well-being }}=.36, p<.05 ; \beta_{\text {mental well-being }}=.37, p<.05\right)$. Thus, Hypotheses $3 a-3 c$ were supported. As shown in Figures 1 to 3, when wives reported lower levels of family identity salience, the relation between husbands' WFC and family satisfaction, physical and mental well-being was more negative than when wives' family identity salience was higher.

\section{【Insert Figures 1, 2, and 3 about here】}

Table 3 shows that the husbands' family identity salience did not significantly moderate any of the relationships between the wives' WFC and the husbands' family satisfaction ( $\beta$ $=.15, p>.05)$, physical well-being $(\beta=-.21, p>.05)$ and mental well-being $(\beta=.06$, $p>.05)$. Thus, Hypotheses $4 a$ to $4 c$ were not supported. 


\section{DISCUSSION}

One key purpose of this study was to examine the crossover effects of individuals' WFC as a stressor on their partner's family satisfaction, physical well-being and mental well-being. The results provided evidence supporting the claim that husbands' WFC is negatively related to wives' family satisfaction, physical and mental well-being and vice versa. These results extended previous studies that demonstrated the crossover effect that one partner's WFC has on the other partner's stressor, such as WFC (e.g., Hammer, et al., 1997; Westman and Etzion, 2005), and show WFC's crossover effects on the other partner's levels of strain, such as family satisfaction and well-being. These results therefore fully support the existence of a "stressor-strain" crossover effect. Additionally, the results were consistent with the COR theory prediction, that is, when individuals are struggling to meet their requirements because of their partner's WFC, they will feel threatened by the potential or actual loss of the valued resources, which leads to lower levels of family satisfaction and well-being. Furthermore, our study found a bilateral crossover process, which supports the argument that WFC crosses over in a bilateral way between couples (e.g., Westman and Etzion, 2005). To our knowledge, the current study is the first to investigate the crossover effects of WFC by using dual-earner couples in China, which accounts for 20 percent of the world's population.

The second purpose was to investigate the moderating effects of family identity salience among WFC crossover effects from the receiver's perspective and to fill the gap in the body of knowledge about the role of individual difference characteristics in the stress crossover process (Brough et al., 2009; Westman, 2002). The results partly confirmed our hypothesis that role salience could play a significant role in the crossover process and could influence the extent of the WFC crossover effects. Our findings also enrich the work-family literature because role salience has been largely neglected in previous studies of work-family issues 
(Biggs and Brough, 2005; Eby et al., 2005). Moreover, our study also raises an interesting question regarding the interaction between gender and role salience (Greenhaus et al., 2012).

First of all, our results demonstrate that wives' family identity salience could alleviate the negative impacts of their husbands' level of WFC on their own levels of family satisfaction and well-being. Wives with high family identity salience maintained a relatively high level of family satisfaction and well-being despite their husbands' high level of WFC, while family satisfaction and well-being declined sharply for those wives with a low family identity salience. The above findings were in accordance with the predictions of COR theory, which emphasizes valued resources as the most critical type of resources (Hobfoll, 1989). Wives with high family identity salience highly valued their family identity as an important personal resource. Even under the stressful conditions of their husbands' high WFC, such resources could alleviate the negative impacts of their husbands' WFC. Moreover, because of their high level of involvement in family life, women might have sufficient recovery from stress (Sanz-Vergel et al., 2011) and experience family mastery (Lu et al., 2011) or family-self facilitation (Demerouti, 2012). All these factors might help wives to gain greater resilience when facing high pressure from their husbands, which could attenuate the negative crossover effects of their husbands' WFC. In contrast, wives with low family identity salience were significantly affected by their husbands' WFC.

Contrary to our hypothesis, we did not find any moderating effect of the husbands' family identity salience. In other words, the husbands' family satisfaction and well-being were negatively affected by their wives' WFC, regardless of whether the men had high or low levels of family identity salience. The reason may lie in a gender role stereotype in China. Men and women are influenced differently by cultural norms regarding gender roles, and they might differ in their role salience or gender role expectations. Men are socialized to be the productive members in the work domain to a greater extent than are women, who are 
socialized to be productive members in the family domain (e.g., Korabik et al., 2008; Powell and Greenhaus, 2010), especially in Chinese society (Choi and Chen, 2006). Our research results also confirmed that men had lower family identity salience than their wives (see the above results of differences test). For Chinese men, extra work after official hours or on weekends is perceived as self-sacrifice made for the benefit of the family, rather than a sacrifice of the family for the selfish pursuit of one's own career (e.g., Spector et al., 2007; Yang et al., 2000); thus, husbands' WFC is more likely to be considered reasonable by their wives. In contrast, when the wives experience WFC, they try to juggle their work and family responsibilities, which is contrary to their expected role. Their husbands may consider WFC a serious threat to family life and personal well-being, whether their own family roles are salient or not.

Overall, our study extended the stress crossover literature by incorporating the individual difference characteristic of the receivers. Similarly, Matthews et al. (2006) found that women's work-to-relationship conflict is positively related to men's relationship tension, whereas men's work-to-relationship conflict is negatively related to women's relationship tension. They suggested that there existed certain moderators buffering the uni-directional crossover process from men to women. Stevens et al. (2006) also suggested that women's work and family conflict can predict men's perception of family cohesion, but not vice-versa. We believe that family identity salience in our study should be an important moderating variable. Family identity salience can buffer the stress crossover process from husbands to wives, but not from wives to husbands. Furthermore, our findings demonstrated that role identity salience is a significant moderator on the effects of gender, which sheds some light on the inconsistencies in previous stress crossover research related to gender differences.

\section{Implications for Research and Practice}


To date, most studies on WFC issue have focused only on the individual as the unit of analysis. This narrow approach is considered one of the significant gaps in WFC research (e.g., Westman and Etzion, 2005). Our study extends this research to include dual-earner couples at the dyad level, with a focus on the role of family identity salience as an important individual difference variable within the crossover process. As a result, our understanding about the mechanism of the crossover process of work and family interface is increased.

One important theoretical contribution of this study is the incorporation of the individual differences variable into the WFC crossover process between dual-earner couples from the receiver's view. The study provides evidence that partners differ in the way they influence each other. Following Westman's (2002) call for more attention to the moderators of crossover, our study treated family identity salience as an individual difference variable and demonstrated that the intensity of the WFC crossover effect may vary according to the family identity salience of the other partner (receiver). Our study not only extended the WFC model (Greenhaus and Beutell, 1985) by investigating the role of role salience among WFC-strain relationships but also integrated individual factors into stress crossover research. This research, therefore, takes a firm step in filling the important gap of considering personal attributes as moderators in crossover literature (Eby et al., 2005; Westman et al., 2009).

Practically, our study was the first to investigate the crossover effects of WFC in China. We also identified the interaction of family identity salience and gender within this crossover process. These results have significant implications for organizational stress management because WFC is becoming increasingly inevitable for Chinese people (Brough et al., 2013; Yang et al., 2000), especially for those dual-earner couples. Our results showed that the negative influence of WFC could go beyond the originator to his or her partner, resulting in reductions in the partner's family satisfaction and well-being. These results may encourage companies to tackle employees' WFC problems through family-friendly policies designed to 
address family care concerns (e.g., childcare, flexible work schedules). It is known that an individual's work-related attitudes and behaviors are largely influenced by the key people with whom he or she interacts (Brough et al., 2009; Westman and Etzion, 2005), especially in collectivist countries such as China (Redding, 1993). It would be wise for employers to broaden their concern to include employees' family lives by implementing family-friendly policies, to attenuate the negative crossover effects (e.g., Brough and O'Driscoll, 2010).

\section{Limitations and Future Directions}

There are some limitations of our study. First, because of self-reported measures, common method bias might exist in this study. However, this study gathered information from both husbands and wives, and the different sources of data avoided the bias to a large extent. Moreover, the interaction effect might have less affected by this bias because it would attenuate rather than inflate the interactions (Spector, 2006). We acknowledge that future research could include objective measures of well-being such as physiological criteria or recorded sick days. Second, we acknowledge that the cross-sectional design prevents any causal conclusions. A longitudinal or diary study design is necessary to clearly demonstrate the causal crossover effects and the buffering effect of family identity salience in the future. Third, we focused on family identity salience in this study. Because individuals could identify themselves with both work and family roles, future studies are recommended to also investigate the impact of work identity salience or its interaction with family identity salience and to explore the possible joint impact on directional work-to-family conflict and family-to-work conflict. Finally, our research sample was drawn from post-doctoral families. In China, this type of job involves a great deal of stress and is therefore ideal for the study of WFC. However, it also limits the generalizability of our findings. These results should therefore be validated using other samples of professional and less educated workers in the future. 


\section{REFERENCES}

Allen, T. D., Herst, D. E. L, Bruck, C. S. and Sutton, M. (2000), “Consequences associated with work-to-family conflict: A review and agenda for future research", Journal of Occupational Health Psychology, Vol. 5 No. 2, pp. 278-308.

Bagger, J. and Li, A. (2012), "Being important matters: The impact of work and family centralities on the family-to-work conflict-satisfaction relationship", Human Relations, Vol. 61 No. 4, pp. 473-500.

Bagger, J., Li, A. and Gutek, B. A. (2008), "How much do you value your family and does it matter? The joint effects of family identity salience, family-interference-with-work, and gender”, Human Relations, Vol. 61 No.2, pp. 187-211.

Bakker, A. B., Demerouti, E. and Dollard, M. F. (2008), "How job demand affect partners' experience of exhaustion: Integrating work-family conflict and crossover theory", Journal of Applied Psychology, Vol. 93 No. 4, pp. 901-911.

Biggs, A. and Brough, P. (2005), "Investigating the moderating influences of gender upon role salience and work-family conflict”, Equal Opportunities International, Vol. 24 No. 2, pp. 30-41.

Brough, P. and O'Driscoll, M. (2005), "Work-family conflict and stress", In Antoniou, A. and Cooper, C. L. (Ed.), Research Companion to Organizational Health Psychology, Edward Elgar, Cheltenham, UK, pp. 346-365.

Brough, P., and O'Driscoll, M. (2010), “Organizational interventions for balancing work and home demands: An overview”, Work \& Stress, Vol. 24 No. 3, pp. 280-297.

Brough, P., O’Driscoll, M., Kalliath, T., Cooper, C. L. and Poelmans, S. (2009), Workplace Psychological Health: Current Research and Practice, Edward Elgar, Cheltenham, UK. Brough, P., Timms, C., Siu, O. L., Kalliath, T., O’Driscoll, M., Sit, C., et al. (2013), 
"Longitudinal application of the Job Demands-Resources model to psychological strain and engagement in cross-national samples", Human Relations, Vol. 66 No. 10, pp.1311-1335.

Burke, P. J. and Stets, J. E. (1999), “Trust and commitment through self-verification”, Social Psychology Quarterly, Vol. 62 No. 4, pp. 347-366.

Burke, P. J. (1991), "Identity processes and social stress", American Sociological Review, Vol. 56 No. 6, pp. 836-849.

Carlson, D. S., Kacmar, K. M. and Williams, L. J. (2000), “Construction and initial validation of a multidimensional measure of work-family conflict", Journal of Vocational Behavior, Vol. 56 No. 2, pp. 249-276.

Carlson, D. S. and Kacmar, K. M. (2000), "Work-family conflict in the organization: Do life role values make a difference?" Journal of Management, Vol. 26 No. 5, pp. 1031-1054.

Cartwright, S. and Cooper, C. L. (2002), ASSET: An Organizational Stress Screening Tool, The Management Guide, RCL Ltd., Manchester, UK.

Choi, J. and Chen, C. C. (2006), "Gender differences in perceived work demands, family demands, and life stress among married Chinese employees", Management and Organization Review, Vol. 2 No. 2, pp. 209-229.

Cinamon, R. G., Weisel, A. and Tzuk, K. (2007), "Work family conflict within the family: crossover effects, perceived parent child interaction quality, parental self-efficacy, and life role attributions", Journal of Career Development, Vol. 34 No. 1, pp. 79-100.

Demerouti, E. (2012), "The spillover and crossover of resources among partners: The role of work-self and family-self facilitation”, Journal of Occupational Health Psychology, Vol. 17 No. 2, pp. 184-195.

Eby, L. T., Casper, W. J., Lockwood, A., Bordeaux, C. and Brinley, A. (2005), "Work and family research in IO/OB: Content analysis and review of the literature (1980-2002)", 
Journal of Vocational Behavior, Vol. 66 No. 1, pp. 124-197.

Edwards, J. R. and Rothbard, N. P. (1999), "Work and family stress and health: An examination of person-environment fit in the work and family domains", Organizational Behavior and Human Decision Processes, Vol. 77 No. 2, pp. 85-129.

Frone, M. R., Russell, M. and Cooper, M. L. (1997), "Relation of work-family conflict to health outcomes: a four-year longitudinal study of employed parents", Journal of Occupational and Organizational psychology, Vol. 70 No. 4, pp. 325-335.

Grandey, A. A. and Cropanzano, R. (1999), “The conservation of resources model applied to work-family conflict and strain”, Journal of Vocational Behavior, Vol. 54 No. 2, pp. $350-370$.

Greenhaus, J. H. and Beutell, N. J. (1985), "Sources of conflict between work and family roles", Academy of Management Review, Vol. 10 No. 1, pp. 76-88.

Greenhaus, J. H., Peng, A.C. and Allen, T. (2012), "Relations of work identity, family identity, situational demands, and sex with employee work hours", Journal of Vocational Behavior, Vol.80 No. 1, pp. 27-37.

Greenhaus, J. H. and Powell, G. N. (2003), "When work and family collide: Deciding between competing role demand", Organizational Behavior and Human Decision Process, Vol. 90 No. 2, pp. 291-303.

Hammer, L. B., Allen, E. and Grigsby, T. D. (1997), "Work-family conflict in dual-earner couples: Within individual and crossover effects of work and family", Journal of Vocational Behavior, Vol. 50 No. 2, pp. 185-203.

Hobfoll, S. E. (1989), “Conservation of resources: A new attempt at conceptualizing stress”, American Psychologist, Vol. 44 No. 3, pp. 513-524.

Hobfoll, S. E. (2001), "The influence of culture, community, and the nested-self in the stress process: Advancing Conservation of Resources Theory", Applied Psychology: An 
International Review, Vol. 50 No. 3, pp. 337-370.

Korabik, K., McElwain, A. K. and Chappell, D. B. (2008), “Integrating gender-related issues into research on work and family", In Korabik, K., Lero, D. S. and Whitehead, D. L. (Ed.), Handbook of Work-Family Integration, Elsevier, New York, NY, pp. 215-232.

Lobel, S. A. and St. Clair, L. (1992), "Effects of family responsibilities, gender, and career identity salience on performance outcomes", Academy of Management Journal, Vol. 35 No. 5, pp. 1057-1069.

Lu, C. Q., Siu, O. L., Chen, W. Q. and Wang, H. J. (2011), “Family mastery enhances work engagement in Chinese nurses: A cross-lagged analysis", Journal of Vocational Behavior, Vol. 78 No. 1, pp. 100-109.

Lu, Z. Z., Maume, D. J. and Bellas, M. L. (2000), “Chinese husbands' participation in household labor", Journal of Comparative Family Studies, Vol. 31 No. 2, pp. 191-215.

Matthews, R.A., Del Priore, R. E., Acitelli, L. K. and Barnes-Farrell, J. L. (2006), "Work-torelationship conflict: Crossover effects in dual-earner couples", Journal of Occupational Health Psychology, Vol. 11 No. 3, pp. 228-240.

O’Driscoll, M., Brough, P. and Kalliath, T. (2009). "Stress and coping”, In Cartwright, S. and Cooper, C. L. (Ed.), The Oxford Handbook of Organizational Well Being, Oxford University Press, Oxford, UK, pp. 237-266.

Powell, G. N. and Greenhaus, J. H. (2010), “Sex, gender, and the work-to-family interface: Exploring negative and positive interdependencies", Academy of Management Journal, Vol. 53 No. 3, pp. 513-534.

Redding, S. G. (1993), The Spirit of Chinese Capitalism, de Gruyter, New York, NY.

Sanz-Vergel, A. I., Demerouti, E., Bakker, A. B. and Moreno-Jimenez, B. (2011), "Daily detachment from work and home: The moderating effect of role salience", Human Relations, Vol. 64 No. 6, pp. 775-799. 
Song, Z., Foo, M., Uy, M. A. and Sun, S. (2011), "Unraveling the daily stress crossover between unemployed individuals and their employed spouses", Journal of Applied Psychology, Vol. 96 No 1, pp.151-168.

Spector, P. E. (2006), "Method variance in organizational research: Truth or urban legend?" Organizational Research Methods, Vol.9 No. 2, pp. 221-232.

Spector, P. E., Allen, T. D., Poelmans, S., Cooper, C. L., Lapierre, L. M., O’Driscoll, M., et al. (2007), “Cross-national differences in relationships of work demands, job satisfaction and turnover intentions with work-family conflict", Personnel Psychology, Vol. 60 No. 4, pp. $805-835$.

Stevens, D. P., Kiger, G. and Riley, P. J. (2006), "His, hers, or ours? Work-to-family spillover, crossover, and family cohesion", Social Science Journal, Vol. 43 No. 3, pp. 425-436.

Stryker, S. (1968), "Identity salience and role performance: The relevance of symbolic interaction theory for family research", Journal of Marriage and the Family, Vol. 30 No. 4, pp. 558-564.

Stryker, S. (1987), "Identity theory: Developments and extensions", In Yardley, K. and Honess, T. (Ed.), Self and Identity: Psychosocial Perspectives, John Wiley, New York, NY, pp. 89-103.

Stryker, S. and Serpe, R. T. (1994), "Identity salience and psychological centrality: Equivalent, overlapping, or complementary concepts?” Social Psychology Quarterly, Vol. 57 No. 1, pp. 16-35.

Ten Brummelhuis, L. L., Haar, J. M. and Van der Lippe, T. (2010), “Crossover of distress due to work and family demands in dual-earner couples: A dyadic analysis", Work \& Stress, Vol. 24 No. 4, pp. 324-341.

Thoits, P. A. (1991), “On merging identity theory and stress research”, Social Psychology Quarterly, Vol. 54 No. 2, pp. 101-112. 
Triandis, H. C. (2004), "The many dimensions of culture", Academy of Management Executive, Vol. 18 No. 1, pp. 88-93.

Warner, M. A. and Hausdorf, P. A. (2009), “The positive interaction of work and family roles: Using need theory to further understand the work-family interface", Journal of Managerial Psychology, Vol. 24 No.4, pp. 372-385.

Westman, M. (2002), "Crossover of stress and strain in the family and workplace", In Perrewé, P. L. and Ganster, D. C. (Ed.), Research in Occupational Stress and Well-Being, Vol. 2, JAI Press/ Elsevier, Greenwich, CT, pp. 143-181.

Westman, M., Brough, P. and Kalliath, T. (2009). Expert commentary on work-life balance and crossover of emotions and experiences: Theoretical and practice advancements. Journal of Organizational Behavior, Vol. 30 No.5, pp. 587-595.

Westman, M. and Etzion, D. L. (2005), “The crossover of work-family conflict from one spouse to the other", Journal of Applied Social Psychology, Vol. 35 No. 9, pp. 19361957.

Westman, M., Vinokur, A., Hamilton, L. and Roziner, I. (2004), "Crossover of marital dissatisfaction during downsizing: A study of Russian Army officers and their spouses", Journal of Applied Psychology, Vol. 89 No. 5, pp. 769-779.

Yang, N. N., Chen, C. C., Choi, J. and Zou, Y. (2000), "Sources of work-family conflict: A Sino-US comparison of the effects of work and family demands", Academy of Management Journal, Vol. 43 No. 1, pp. 113-123. 
Table 1. Means, standard deviance, reliabilities, and correlations $(N=212)$

\begin{tabular}{|c|c|c|c|c|c|c|c|c|c|c|c|c|c|c|c|c|c|c|}
\hline Variables & $M$ & $S D$ & 1 & 2 & 3 & 4 & 5 & 6 & 7 & 8 & 9 & 10 & 11 & 12 & 13 & 14 & 15 & 16 \\
\hline 1.WFC of husband & 2.88 & .52 & $(.86)$ & & & & & & & & & & & & & & & \\
\hline 2.WFC of wife & 2.91 & .57 & $.48^{* * *}$ & $(.89)$ & & & & & & & & & & & & & & \\
\hline 3.FIS of husband & 3.74 & .80 & .08 & .04 & $(71)$ & & & & & & & & & & & & & \\
\hline 5.FS of husband & 4.76 & .81 & $-.26^{* * *}$ & $-.32^{* * *}$ & .06 & .13 & $(.87)$ & & & & & & & & & & & \\
\hline 6.FS of wife & 4.53 & .86 & $-.24^{* *}$ & $-.30^{* * *}$ & .11 & $.25^{* * *}$ & $.50^{* * *}$ & $(.86)$ & & & & & & & & & & \\
\hline 7.PW of husband & 4.03 & .87 & $-.46^{* * *}$ & $-.26^{* * *}$ & .01 & $.15^{*}$ & $.24^{* *}$ & $.23^{* *}$ & $(.87)$ & & & & & & & & & \\
\hline 8.PW of wife & 4.04 & .93 & $-.23^{* *}$ & $-.38^{* * *}$ & .02 & .07 & $.28^{* * *}$ & $.31^{* * *}$ & $.56^{* * *}$ & $(.87)$ & & & & & & & & \\
\hline 9.MW of husband & 4.40 & .80 & $-.47^{* * *}$ & $-.28^{* * *}$ & .05 & .11 & $.32^{* * *}$ & $.29^{* * *}$ & $.76^{* * *}$ & $.58^{* * *}$ & $(.91)$ & & & & & & & \\
\hline 10.MW of wife & 4.39 & .87 & $-.20^{* *}$ & $-.41^{* * *}$ & $.16^{*}$ & .05 & $.24^{* *}$ & $.32^{* * *}$ & $.45^{* * *}$ & $.71^{* * *}$ & $.58^{* * *}$ & $(.92)$ & & & & & & \\
\hline 11.Children & - & - & .14 & -.02 & .02 & .09 & .03 & -.04 & -.01 & $.14^{* * *}$ & .02 & .01 & & & & & & \\
\hline 12.Elders & - & - & $.26^{* *}$ & $.17^{*}$ & .01 & -.02 & $-.15^{*}$ & $-.14^{* * *}$ & $-.25^{* * *}$ & -.05 & $-.16^{*}$ & -.10 & $.37^{* * *}$ & & & & & \\
\hline 13.Age of husband & 35.64 & 4.50 & -.02 & .05 & .07 & .10 & $.15^{*}$ & .02 & -.01 & .00 & -.02 & -.08 & $.29^{* * *}$ & -.03 & & & & \\
\hline 14.Age of wife & 33.94 & 4.46 & -.03 & .01 & .08 & .01 & .08 & .00 & -.05 & -.02 & -.05 & -.12 & $.28^{* * *}$ & -.01 & $.84^{* * *}$ & & & \\
\hline $\begin{array}{l}\text { 15.Education of } \\
\text { husband }\end{array}$ & 4.71 & .67 & .02 & .12 & -.05 & $.25^{* * *}$ & -.03 & -.11 & .04 & .01 & -.02 & .03 & .10 & .10 & -.02 & -.08 & & \\
\hline
\end{tabular}

Note. Alpha reliabilities are in parentheses on the diagonal. FIS= family identity salience, $\mathrm{FS}=$ family satisfaction, $\mathrm{PW}=$ physical well-being, $\mathrm{MW}=$ mental well-being, Children=Whether there were children to take care of $(0=$ "No", $1=$ "Yes"), Elders= Whether there were elders living together $(0=$ "No", $1=$ "Yes" $)$, Education= education level(1=" high school degree", 2="technical degree", 3="bachelor degree", 4="master degree", 5="doctor degree")

$* p<.05, * * p<.01, * * * p<.001$. 
Table 2. Hierarchical regression analyses predicting wives' family satisfaction and well-being $(N=212)$

\begin{tabular}{|c|c|c|c|c|c|c|c|c|c|}
\hline \multirow[b]{2}{*}{ Variables } & \multicolumn{3}{|c|}{ Family satisfaction of Wife } & \multicolumn{3}{|c|}{ Physical Well-being of Wife } & \multicolumn{3}{|c|}{ Mental Well-being of Wife } \\
\hline & $\beta$ & $R^{2}$ & $\Delta R^{2}$ & $\beta$ & $R^{2}$ & $\Delta R^{2}$ & $\beta$ & $R^{2}$ & $\Delta R^{2}$ \\
\hline Step 1 & & .004 & & & .035 & & & .038 & \\
\hline Whether there were children to take care of & .03 & & & $.20^{*}$ & & & .09 & & \\
\hline Whether there were elders living together & -.14 & & & -.13 & & & -.14 & & \\
\hline Age of husband & .09 & & & -.05 & & & -.03 & & \\
\hline Age of wife & -.09 & & & -.06 & & & -.14 & & \\
\hline Education of husband & -.09 & & & -.09 & & & -.07 & & \\
\hline Education of wife & .04 & & & $-.18 *$ & & & $-.20 *$ & & \\
\hline Step 2 & & .048 & $.050 * * *$ & & .068 & $.037 *$ & & .056 & $.023^{*}$ \\
\hline WFC of husband & $-.23 * * *$ & & & $-.20 * *$ & & & $-.16^{*}$ & & \\
\hline Step 3 & & .110 & $.070 * * *$ & & .064 & .000 & & .052 & .001 \\
\hline Family identity salience of wife & $.28 * * *$ & & & .00 & & & -.03 & & \\
\hline Step 4 & & .130 & $.017^{*}$ & & .075 & $.015^{*}$ & & .065 & $.017^{*}$ \\
\hline WFC of husband * family identity salience of wife & $.38^{*}$ & & & $.36^{*}$ & & & $.37 *$ & & \\
\hline
\end{tabular}

$* p<.05, * * p<.01, * * * p<.001$. 
Table 3. Hierarchical regression analyses predicting husband's family satisfaction and well-being $(N=\mathbf{2 1 2})$

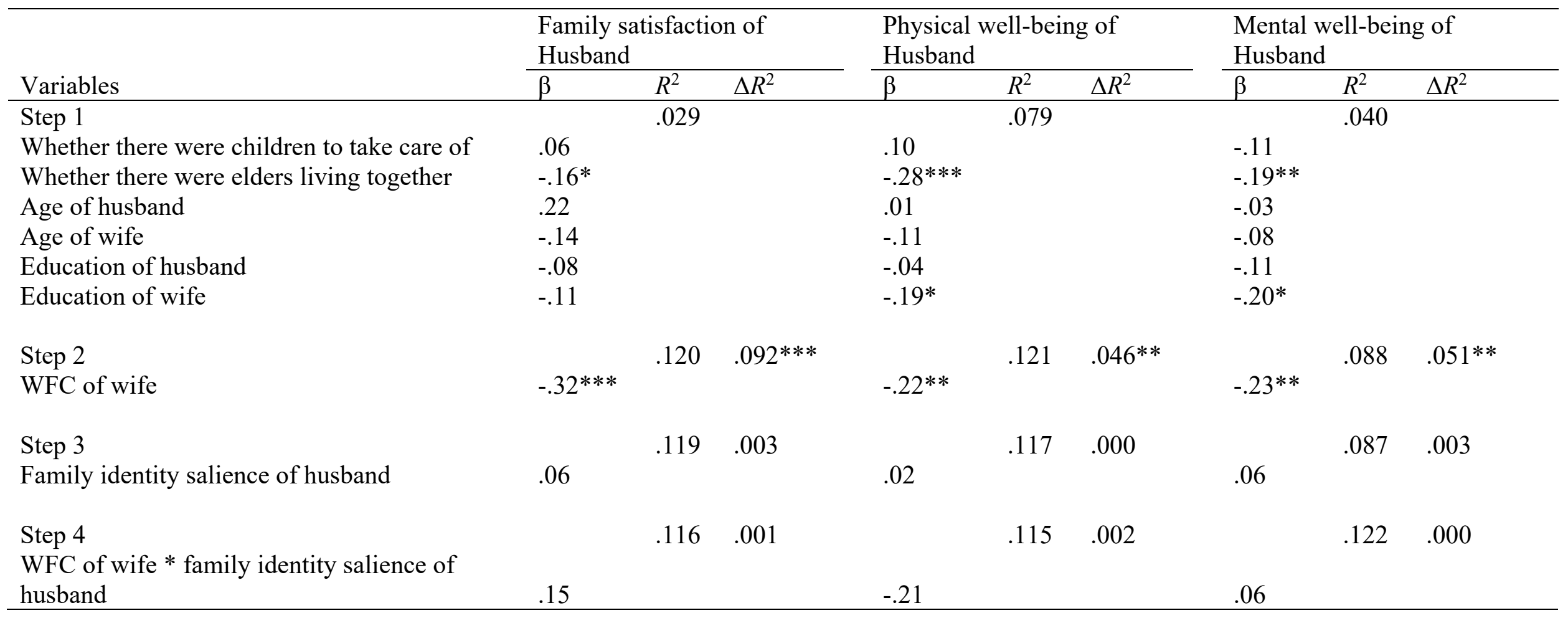

$* p<.05,{ }^{* *} p<.01, * * * p<.001$. 